\title{
HUBUNGAN POLA KONSUMSI, ASUPAN SERAT, KARBOHIDRAT SEDERHANA DAN KALIUM DENGAN KADAR TRIGLISERIDA PADA PASIEN PENYAKIT JANTUNG DI POLI PENYAKIT JANTUNG
}

\author{
Tonny C Maigoda, Ps. Kurniawati, Darwis \\ Poltekkes Bengkulu, Jurusan Gizi Jl. Indragiri No.3 Bengkulu \\ Poltekkes Bengkulu, Jurusan Kebidanan Jl. Indragiri No.3 Bengkulu \\ Poltekkes Bengkulu, Jurusan Gizi Jl. Indragiri No.3 Bengkulu
}

\begin{abstract}
Deaths from heart and blood vessel disease in Indonesia by $26.3 \%$. We assumed that only the low-fat diet will lower triglyceride levels, it is not entirely true. Since the main cause is excessive sugar consumption. It is therefore also important to avoid foods that are carbohydrates that have a high glycemic value, which is the glycemic value is how much carbohydrate that can be converted into sugar (Candra, 2010). The objectives of the study know the relationship between the pattern of consumption, fiber intake, simple carbohydrates and potassium in patients with triglyceride levels in the Heart Hospital M. Yunus. Obeservasional research method using crosssectional design. Sampling in this study using non-probability sampling technique particularly with the way many as 123 people Proposive Sampling. By Karl Pearson correlation test, there is a strong relationship and patterned negative $(p=0.000)$ in this case based on the composition of the dish with triglyceride levels. There is a relationship between the intake of simple carbohydrates with triglyceride levels of heart disease patients $(p=0.004)$. It can be concluded that the dominant factor associated with triglyceride levels of heart disease patients are carbohydrates derived from food and beverage patients.
\end{abstract}

\begin{abstract}
Abstrak : Kematian akibat penyakit jantung dan pembuluh darah di Indonesia sebesar 26,3\%. Faktor pemicu serangan jantung adalah, mengkonsumsi makanan berkolesterol tinggi, kurang gerak, malas olahraga, stress dan kurang istirahat. Tujuan Penelitian, Mengetahui hubungan pola konsumsi, asupan serat, karbohidrat sederhana dan kalium dengan kadar trigliserida pada pasien Jantung di RSUD M. Yunus. Metode Penelitian. penelitian obeservasional dengan menggunakan rancangan cross-sectional. Pengambilan sampel dalam penelitian ini menggunakan teknik Non Probability Sampling khususnya dengan cara Proposive Sampling sebanyak 123 orang. Hasil, Dengan uji korelasi Karl Pearson pada taraf signifikasi $\alpha=0,05$ didapatkan hasil bahwa nilai $r=$ $-0,385$ dan nilai $p=0.000$ yang menunjukkan hubungan pola konsumsi dalam hal ini berdasarkan susunan hidangan dengan kadar trigliserida menunjukkan hubungan yang kuat dan berpola negative. Hubungan Asupan Karbohidrat Sederhana dengan kadar Trigliserida diuji korelasi Karl Pearson pada taraf signifikasi $\alpha=0,05$ didapatkan bahwa hasil $\mathrm{p}$ value $=0,004$. Setelah dibandingkan dengan $\alpha=0,05$ ternyata $\mathrm{p}$ value $<\alpha$. Dengan demikian secara analitik hipotesis penelitian bermakna, yaitu ada hubungan antara asupan karbohidrat sederhana dengan kadar trigliserida pasien penyakit jantung. Sedangkan keeratan hubungannya adalah sedang. Hal ini dapat dilihat dari $\mathrm{r}$ hitung yaitu 0,261.Kesimpulan, Ada hubungan antara asupan karbohidrat sederhana dengan kadar trigliserida penderita penyakit jantung. Tidak ada hubungan antara pola konsumsi berdasarkan frekuensi bahan makanan dengan kadar trigliserida penderita penyakit jantung. Tidak ada hubungan antara asupan serat dengan kadar trigliserida penderita penyakit jantung. Tidak ada hubungan antara asupan kalium dengan kadar trigliserida penderita penyakit jantung. Faktor dominan yang berhubungan dengan kadar trigliserida pasien penyakit jantung adalah karbohidrat yang berasal dari makanan dan minuman pasien.
\end{abstract}

Kata Kunci: pola konsumsi, asupan serat, karbohidrat sederhana, kalium, kadar trigliserida.

Menurut National Cholesterol Education Program Expert Panel on Detection Evaluation, and Treatment of High Blood Cholesterol in Adults Adult Treatment Panel III (NCEP-ATP III) tahun 2001, (dalam Jalal, 2004), sindroma metabolik adalah sekelompok kelainan metabolik lipid maupun nonlipid, merupakan faktor risiko penyakit jantung koroner terdiri atas obesitas, dislipidemia aterogenik (ka- 
dar trigliserida dan kolesterol meningkat, sedangkan highdensity lipoprotein/HDL rendah, hipertensi, dan peningkatan kadar glukosa plasma. Menurut WHO (1990), kematian karena penyakit jantung dan pembuluh darah adalah 12 juta/tahun pembunuh nomor satu umat manusia, dibandingkan dengan kematian yang disebabkan oleh diare 5 juta, kanker 4,8 juta dan tuberkulosis (TBC) 3 juta. Padahal dikatakan bahwa Penyakit Jantung dan Pembuluh Darah (PJPD) ini adalah suatu penyakit yang dapat dicegah, $50 \%$ kematian dini dapat dicegah dengan upayaupaya pencegahan yang mengenai perubahan gaya hidup (Jota, 2002). Berdasarkan survei kesehatan rumah tangga tahun 2001 kematian akibat penyakit jantung dan pembuluh darah di Indonesia sebesar 26,3\%. Faktor pemicu serangan jantung adalah mengkonsumsi makanan berkolesterol tinggi, kurang gerak, malas olahraga, stress dan kurang istirahat. Dari sepuluh penyakit tidak menular yang dikelompokkan, dinyatakan bahwa penyakit jantung termasuk urutan kesepuluh, yaitu sebanyak $11 \%$ dari total penduduk (Profil Kesehatan Kota Bengkulu, 2006).

RSUD Dr.M.Yunus merupakan satusatunya rumah sakit rujukan di Provinsi Bengkulu, berdasarkan data yang diperoleh dari medical record Rumah Sakit Dr. M. Yunus Bengkulu pada tahun 2009 pasien jantung berjumlah 1433 orang dan berdasarkan data yang diperoleh dari data terolah instalasi gizi tahun 2009 penyakit jantung merupakan penyakit terbanyak pertama diantara penyakit degeneratif lainnya yang berjumlah 322 pasien $(36,05$ $\%)$. Sedangkan jumlah kunjungan baru yang di dapat dari poli jantung pada tahun 2010 dari triwulan I hingga triwulan III berjumlah 534 orang.

Selama ini kita mengira bahwa ha-nya dengan diet rendah lemak akan menurunkan kadar trigliserida, ternyata tidak sepenuhnya benar. Karena penyebab utamanya adalah konsumsi gula yang berlebihan. Oleh karena itu makanan yang penting juga dihindari adalah karbohidrat yang mempunyai nilai glikemik yang tinggi, yang dimaksud dengan nilai glikemik adalah seberapa besar karbohidrat yang dapat diubah menjadi gula (Candra, 2010).

Kalium merupakan unsur organik yang penting di dalam cairan intraselul-ar, penting dalam transmisi impuls-impuls saraf, penting untuk kontraksi otot dan penting untuk pertumbuhan tubuh, memelihara keseimbangan asam dan basa dalam tubuh, sebagai katalistor dalam reaksi kimia dan biologis dalam tubuh, memelihara denyut jantung dan mengatur pelepasan insulin dari pankreas. Selanjutnya kalium berperan dalam mengeluarkan zat-zat hasil metabolite dari kompartemen intraselular kedalam kompartemen interstisial dan selanjutnya ke kompartemen intravascular untuk di transport ke jaringan lain atau di bawa ke alatalat ekskresi untuk di keluarkan dari tubuh (Sediaoetama, 2008)

\section{BAHAN DAN CARA KERJA}

Penelitian ini menggunakan metode penelitian survei analitik dengan desain crosssectional. Sampel diambil menggunakan purposive sampling sebanyak 123 orang, yaitu pasien jantung yang termasuk dalam kriteria inklusi diantaranya adalah tercatat sebagai pasien jantung di Poli Jantung RSUD Dr. M.Yunus, bersedia menjadi sampel penelitian, responden harus memiliki data laboratorium (kadar trigliserida), pasien dengan diagnosa medis penyakit jantung, usia dewasa (20-65 tahun), dan bertempat tinggal di Bengkulu.

Penelitian ini dilakukan di Poli Jantung RSUD dr. M. Yunus Bengkulu. Da-ta Identitas pasien, riwayat nutrisi dan riwayat penyakit pasien diperoleh dari wawancara dan observasi pada pasien berdasarkan pedoman pengumpulan data, dan data pencatatan langsung yaitu asupan makanan pasien dengan metode food recall $3 \times 24$ jam. Analisis data secara statistik dengan uji korelasi product moment dari 
Karl Pearson dengan menggunakan perangkat lunak dengan $\alpha=5 \%$.

\section{HASIL}

Hasil penelitian disajikan dalam analisis univariat dari setiap variabel independen dan dependen. Penyajian dilanjutkan dengan hasil analisis bivariat dan multivariat yang bertujuan untuk mengetahui hubungan antara variable independen dengan variable dependen.

Pada penelitian ini jenis kelamin lakilaki lebih banyak yaitu 68 sampel $(55,3 \%)$ dibandingkan perempuan 55 sampel (44,7\%). Pada penelitian ini pola konsumsi pasien dilihat dari kebiasaan makan pasien seharihari yang meliputi jenis makanan (susunan hidangan) dan frekuensi pengunaan bahan makanan, data didapat menggunakan metode wawancara dengan alat bantu kuesioner. Pada tabel ini dapat dilihat distribusi karakteristik pola konsumsi yang meliputi jenis makanan (susunan hidangan) dan frekuensi pengunaan bahan makanan. Karakteristik jenis hidangan yang tercermin dalam susunan hidangan dengan katagori baik sebesar $50,4 \%$. Frekuensi konsumsi protein hewani sering sebesar $87,8 \%$.
Rata-rata tingkat konsumsi serat penduduk Indonesia secara umum yaitu sebesar 10.5 gram/orang/hari, baru mencapai sekitar separuh dari kecukupan serat yang dianjurkan. Kecukupan serat untuk orang dewasa berkisar antara 20-35 gram/hari atau 10-13 gram serat untuk 1000 kalori. Pada penelitian ini hanya 4 orang atau 3,3\% sampel yang konsumsi seratnya baik sesuai dengan angka kecukupan serat untuk orang dewasa. Untuk memelihara kesehatan, WHO menganjurkan agar 55-75\% konsumsi energi total berasal dari karbohidrat kompleks dan hanya $10 \%$ berasal dari gula sederhana. Pada penelitian ini asupan karbohidrat sederhana minimum 0,25 gr dan maksimum $42 \mathrm{~g} /$ hari.

Kebutuhan normal akan kalium sebanyak 3,5-5 $\mathrm{mmol} / \mathrm{dl}$ sehari (Almatsier, 2003). Jumlah konsumsi kalium per hari 50-100 mEq atau sekitar 3,7-7,4 g kalium klorida per hari. Pada penelitian ini 63 orang atau $51,2 \%$ dibawah kecukupan konsumsi kalium per hari. Pada penelitian pasien dengan kadar trigliserida normal sebanyak 56\%. Tabel berikut ini adalah distribusi subjek penelitian berdasarkan kadar trigliserida.

Tabel 1. Hubungan Pola Konsumsi berdasarkan Susunan Hidangan, bahan makanan dan Asupan Serat, Asupan Karbohidrat Sederhana, Asupan Kalium dengan Kadar Trigliserida

\begin{tabular}{lcc}
\multicolumn{1}{c}{ Variabel } & \multicolumn{1}{c}{$\begin{array}{c}\text { Nilai } \boldsymbol{r} \\
\text { Pearson correlation }\end{array}$} & Nilai P \\
\hline Susunan Hidangan dengan Kadar Trigliserida & -0.385 & 0.000 \\
Frekuensi bahan makanan dengan Kadar Trigliserida & -0.008 & 0.929 \\
Asupan serat dengan kadar Trigliserida & -156 & 0,085 \\
Asupan Karbohidrat Sederhana dengan kadar Trigliserida & 0,261 & 0,004 \\
Asupan Kalium dengan kadar Trigliserida & $-0,036$ & 0,691 \\
\hline
\end{tabular}

Berdasarkan hasil uji analitik dengan uji korelasi Karl Pearson pada taraf signifikasi $\alpha=0,05$ didapatkan hasil bahwa nilai $r=-0,385$ dan nilai $\mathrm{p}=0.000$ yang menunjukkan hubungan pola konsumsi dalam hal ini berdasarkan susunan hidangan dengan kadar trigliserida menunjukkan hubungan yang kuat dan berpola negatif artinya semakin baik susunan hidangan semakin rendah kadar trigliseridanya.
Pada hasil diatas diperoleh nilai $\mathrm{p}=$ 0.929 yang menunjukkan tidak ada hubungan pola konsumsi dalam hal ini berdasarkan frekuensi bahan makanan dengan kadar trigliserida.

Berdasarkan hasil uji analitik dengan uji korelasi Karl Pearson pada taraf signifikasi $\alpha=0,05$ didapatkan bahwa hasil $p$ value $=0,085$. Setelah dibandingkan dengan $\alpha=0,05$ ternyata $p$ value $>\alpha$. De- 
ngan demikian secara analitik hipotesis penelitian tidak ada hubungan yang bermakna, yaitu ada tidak ada hubungan antara asupan serat dengan kadar trigliserida pasien penyakit jantung. Sedangkan nilai $r$ hitung negatif menunjukkan hubungan antarvariabel adalah negatif. Artinya jika asupan serat semakin tinggi maka kadar trigliserida semakin rendah atau sebaliknya jika asup-an karbohidrat sederhana rendah maka kadar trigliserida semakin tinggi.

Berdasarkan hasil uji analitik dengan uji korelasi Karl Pearson pada taraf signifikasi $\alpha=0,05$ didapatkan bahwa hasil $p$ value $=0,004$. Setelah dibandingkan dengan $\alpha=0,05$ ternyata $\mathrm{p}$ value $<\alpha$. Dengan demikian secara analitik hipotesis penelitian bermakna, yaitu ada hubungan antara asupan karbohidrat sederhana dengan kadar trigliserida pasien penyakit jantung.

Sedangkan keeratan hubungannya adalah sedang. Hal ini dapat dilihat dari $\mathrm{r}$ hitung yaitu 0,261 . Nilai $r$ hitung positif menunjukkan hubungan antara variabel adalah positif. Artinya jika asupan karbohidrat sederhana semakin tinggi maka kadar trigliserida semakin tinggi juga atau sebaliknya jika asupan karbohidrat sederhana rendah maka kadar trigliserida semakin rendah.

Berdasarkan hasil uji analitik dengan uji korelasi Karl Pearson pada taraf signifikasi $\alpha=0,05$ didapatkan bahwa ha-sil $p$ value $=0,691$. Setelah dibanding-kan dengan $\alpha=0,05$ ternyata $p$ value $>\alpha$. Dengan demikian secara analitik hipotesis penelitian tidak bermakna, yaitu tidak ada hubungan antara asupan kalium dengan kadar trigliserida pasien penyakit jantung.

\section{Analisis Multivariat}

Analisis multivariat regresi linear merupakan analisis hubungan antara beberapa variable independen dengan satu variabel dependen. Yaitu untuk mengetahui faktor- faktor yang berhubungan dengan kadar trigliserida. Variabel-variabel pada analisis bivariat memiliki kemaknaan cukup kuat ( $\mathrm{p}$ value $<0,25$ ) serta diduga memiliki kontribusi penting bagi kadar trigiliserida. Uji ini dimaksudkan untuk mencari model yang paling cocok untuk mengetahui faktor yang paling dominan diantara variabel indevenden yang berhubungan dengan variabel dependen.

Tahapan pertama dalam analisis multivariat ini adalah memilih variabel kandidat multivariat. Hasil dari analisi bivariat dengan korelasi didapatkan nilai $p$ value untuk variabel susunan hidangan $(\mathrm{p}=$ $0.000)$, frekuensi bahan makanan ( $\mathrm{p}=$ 0.925), asupan serat $(\mathrm{p}=0.085)$, asupan karbohidrat $(\mathrm{p}=0.004)$ dan asupan kalium $(\mathrm{p}=0.691)$, dari hasil tersebut da-pat disimpulkan bahwa variabel susunan hidangan dan asupan karbohidrat mempunyai $\mathrm{p}$ value $<0.25$, dengan demikian kedua variabel tersebut dapat lajut masuk ke pemodelan multivariat. Variabel frekuensi bahan makanan, asupan serat dan asupan kalium mempunyai nilai $\mathrm{p}$ value $>0.25$ sehingga tidak bisa masuk ke multivariat, namun demikian oleh karena secara substansi merupakan faktor yang sangat penting terhadap kadar trigliserida, maka variabel tetap diikutkan dalam analisis multivariat.

Berdasarkan hasil analisis multivariat dimana variabel dianalisis secara bersamaan seperti terlihat pada tabel 2 menunjukkan didapatkan nilai $\mathrm{R}$ Squre 0.182 artinya kelima variabel indevenden dapat menjelaskan variabel kadar trigliserida sebesar $18.2 \%$ sedangkan sisanya dijelaskan oleh variabel lain. Dari hasil uji statistik didapatkan $p$ value $=0.000$ berarti persamaan garis linier secara keseluruhan sudah signifikan. Dari lima variabel ada 3 variabel yang $\mathrm{p}$ valuenya 0.05 yaitu frekuensi bahan makanan, asupan kalsium dan asupan serat. Tahap selanjutnya mengeluarkan variabel yang $\mathrm{p}>0,05$ yang dimulai dari $\mathrm{p}$ value yang terbesar. 
Tabel 2. Hasil analisis Multivariat Regresi linier antara susunan hidangan, frekuensi bahan makanan, asupan karbohidrat, asupan serat dan asupan kalium

\begin{tabular}{|c|c|c|c|c|}
\hline $\begin{array}{ll}\text { No } & \text { Variabel } \\
\mathrm{R} \text { square }=0.182\end{array}$ & B & Beta & $\mathrm{T}$ & $P$ value \\
\hline Susunan hidangan & -52.535 & -0.361 & -3.367 & 0.001 \\
\hline Frekuensi bahan makanan & 7.362 & 0.049 & 0.498 & 0.609 \\
\hline Asupan serat & 0.353 & 0.022 & 0.185 & 0.853 \\
\hline Asupan karbohdrat & 2.336 & 0.215 & 2.518 & 0.013 \\
\hline Asupan kalium & -0.86 & 0.03 & -0.075 & 0.972 \\
\hline Konstan & 199.287 & & 6.970 & 0.000 \\
\hline
\end{tabular}

Pada tabel diatas terlihat bahwa variabel indevenden yang masuk model regresi adalah susunan hidangan dan asupan karbohidrat. Dari hasil diatas, persamaan regresi yang diperoleh adalah kadar tri- gliserida $=207.943-48.622 \mathrm{SH}+2.443$ ACHO. Dengan model persamaan ini, dapat memperkirakan kadar trigliserida dengan menggunakan variabel susunan hidangan dan asupan karbohidat.

Tabel 3. Hasil Analisis Multivariat Regresi Linier Susunan Hidangan dan Asupan Karbohidrat dengan Kadar Trigliserida

\begin{tabular}{lccccc}
\hline No & Variabel & B & Beta & T & P value \\
R square $=0.179$ & & & & \\
\hline Susunan hidangan & & -48.622 & 0.334 & -4.013 & 0.000 \\
Asupan karbohidrat & 2.443 & 0.225 & 2.706 & 0.008 \\
Konstan & 207.943 & & 9.574 & 0.000 \\
\hline
\end{tabular}

\section{PEMBAHASAN}

Hubungan Asupan Serat dengan Kadar Trigliserida

Pada penelitian ini hanya 4 orang a-tau 3,3\% sampel yang konsumsi seratnya baik sesuai dengan angka kecukupan ser-at untuk orang dewasa. Hubungan antara asupan serat dengan trigliserida adalah lemah dan berpola negatif dengan nilai $r$ 0,155 artinya semakin tinggi asupan se-rat semakin rendah kadar trigliserida. Hasil penelitian ini sejalan dengan hasil penelitian yang dilakukan oleh Jalal (2006) tentang Hubungan Lingkar Pinggang dengan Kadar Trigliserida Darah dan Tekanan Darah, Universita Andalas, Sumatera Barat. Di dapatkan Rata-rata asupan serat responden a dalah 9,5 gr, dengan asupan tertinggi $20 \mathrm{gr}$, dan asupan terendah 1,49 gr. Di ikuti dengan hasil laboratorium trigliserida yang tinggi yaitu sebanyak $46.7 \%$, sehingga tergambar ada hubungan korelasi. Kemudian didukung oleh pendapat Koswara (2009), yang menyatakan bahwa serat dapat membantu mengurangi tingginya kolestrol darah, memperbaiki kadar trigliserida dan membantu mengatur kadar gula dalam darah agar stabil, daam saluran pencernaan harus tersedia asam empedu supaya system metabolisme lemak tidak terganggu, yang berperan dalam mengemulsikan lemak seperti triglisrida sehingga terurai menjadi asam lemak yang akan diserap tubuh, dengan asupan normal serat yang dianjurkan yaitu $25 \mathrm{~g} / \mathrm{hari}$.

Hasil analisa asupan serat yang didapat tidak terdistribusi secara normal karena rata-rata asupan serat yang di-dapat masih dibawah angka kecukupan yang di anjurkan, sedangkan kadar trigliserida yang didapatkan bervariasi atau terdistribusi secara normal, sehingga dari hasil uji statistik didapat tidak ada hubungan yang bermakna, yang ditunjukkan oleh nilai $\mathrm{p}$ value $(0,086)>0,05$. Hal ini bisa saja disebabkan sampel peneliti yang masih kurang besar untuk membuktikan hasil uji, berdasarkan hasil recall 3x24 jam rata-rata asupan serat responden kurang dari asupan serat yang dianjurkan untuk penderita jantung, yaitu $25 \mathrm{~g} / \mathrm{hr}$ sehingga sulit untuk 
mengabsorbsi kadar Trigliserida dalam darah.

Pada penelitian ini juga terdapat beberapa kelemahan yang mempengaruhi hasil dari penelitian yaitu dari metode yang digunakan untuk mengumpulkan data yaitu metode recall $3 \times 24$ jam dan wawancara yang ketepatannya sangat tergantung pada daya ingat responden. Estimasi yang dilakukan juga mempengaruhi hasil dari perhitungan kalori asupan makaan yang dikonsumsi responden, kemungkinan adanya perbedaan untuk porsi dan Ukuran Rumah Tangga (URT) antara responden dan peneliti dalam mengestimasi makanan yang dikonsumsi responden.

\section{Hubungan Asupan Karbohidrat Sederhana de- ngan Kadar Trigliserida}

Hasil uji analitik dengan uji korela-si Karl Pearson pada taraf signifikasi $\alpha=$ 0,05 didapatkan bahwa hasil $\mathrm{p}$ value $=$ 0,003 . Setelah dibandingkan dengan $\alpha=$ 0,05 ternyata $\mathrm{p}$ value $<\alpha$. Dengan demikian secara analitik hipotesis penelitian bermakna, yaitu ada hubungan antara asupan karbohidrat sederhana dengan kadar trigliserida pasien penyakit jantung. Sedangkan keeratan hubungannya adalah sedang, dilihat dari $r$ hitung yaitu 0,264 nilai $r$ hitung positif menunjukkan hubungan antarvariabel adalah positif, artinya jika asupan karbohidrat sederhana semakin tinggi maka kadar trigliserida semakin tinggi juga atau sebaliknya jika asupan karbohidrat sederhana rendah maka kadar trigliserida semakin rendah.

Rata-rata asupan karbohidrat responden adalah 263,5 g, dengan asupan tertinggi 563,7 g, dan asupan terendah 105 $\mathrm{g}$, dengan hasil laboratorium trigliserida yang tinggi yaitu sebanyak $46.7 \%$, sehingga tergambar ada hubungan korelasi positif antara asupan karbohidrat dengan kadar trigliserida pada sampel penelitian. Trigliserida dalam tubuh berasal dari lemak makanan atau dari hasil perubahan unsur-unsur energi yang berlebihan dalam tubuh. Trigliserida di- angkut oleh Very Low Density Lipoprotein (VLDL) atau kilomikron ke jaringan tubuh sebagai sumber energi atau ke jaringan lemak untuk disimpan. Penyebab utama peningkatan trigliserida adalah faktor genetik, kegemukan, alkohol, hormon estrogen, obat-obatan, diabetes militus tidak terkontrol, penyakit ginjal kronik, penyakit hati serta asupan karbohidrat sederhana yang berlebihan (Almatsier, 2004). Almatsier (2002), ju-ga menjelaskan bahwa karbohidrat yang penting dalam ilmu gizi dibagi dalam dua golongan, yaitu karbohidrat sederhana dan karbohidrat kompleks. Jenis karbohidrat terdiri atas karbohidrat sederhana atau gula sederhana, karbohidrat kompleks mempunyai lebih dari dua unit gula sederhana didalam satu molekul. Trigliserida adalah sejenis lemak kita mengira bahwa dengan diet rendah lemak akan menurunkan kadar trigliserida, ternyata tidak sepenuhnya benar. Penyebab utama adalah konsumsi gula yang berlebihan. Oleh karena itu makanan paling penting yang harus dihindari adalah karbohidrat yang mempunyai nilai glikemik yang tinggi nilai glikemik adalah seberapa besar karbohidrat yang dapat diubah menjadi gula (Candra, 2010).

\section{Hubungan Asupan Kalium dengan Kadar Tri- gliserida}

Hasil uji analitik dengan uji korela-si Karl Pearson, didapatkan hasil $\mathrm{p}$ value $=$ 0,760. Setelah dibandingkan dengan $\alpha=$ 0,05 ternyata $\mathrm{p}$ value $>\alpha$. Dengan demikian secara analitik hipotesis penelitian tidak bermakna, yaitu tidak ada hubungan antara asupan kalium dengan kadar trigliserida pasien penyakit jantung. Hal ini bisa saja disebabkan sampel peneliti yang masih kurang besar untuk membuktikan hasil uji, berdasarkan hasil recall 3x24 jam rata-rata asupan kalium responden sesuai dengan yang dianjurkan yaitu /hari.

Hasil penelitian ini mendukung oleh pendapat Sediaoetama, (2008) yang menyatakan bahwa fungsi dari kalium tubuh adalah merupakan unsur organik yang penting di dalam cairan intraselular, Tekanan 
osmotik oleh ion-ion dan ikatan-ikatan organik menyebabkan aliran air dari kompartemen yang satu ke kompartemen yang lain. Aliran ini dikendalikan oleh selisih antara gaya tarik osmotik dan gaya dorong tekanan hydrostatik di dalam pembuluh darah. Kemudian zat-zat metabolite dikeluarkan dari kompartemen intraselular kedalam kompartemen interstisial dan selanjutnya ke kompartemen intravascular untuk di transport ke jaringan lain atau di bawa ke alat-alat ekskresi untuk di keluarkan dari tubuh.

Pada penelitian ini juga terdapat beberapa kelemahan yang mempengaruhi hasil dari penelitian, dari metode yang digunakan untuk mengumpulkan data yaitu metode recall $3 \times 24$ jam dan wawancara yang ketepatannya sangat tergantung pada daya ingat responden. Estimasi yang dilakukan juga mempengaruhi hasil dari perhitungan kalori asupan makanan yang dikonsumsi responden, kemungkinan adanya perbedaan untuk porsi dan Ukuran rumah tangga (URT) antara responden dan peneliti dalam mengestimasi makanan yang dikonsumsi responden.

\section{KESIMPULAN}

Dari hasil penelitian dan pembahasan yang telah dikemukakan diatas dapat diambil kesimpulan sebagai berikut : Sebagian besar $(87,8 \%)$ responden dengan

\section{DAFTAR KEPUSTAKAAN}

Achmadi, Endang L 2007, Gizi dan Kesehatan Masyarakat Departemen Gizi dan Kesehatan Masyarakat FKMUI, PT Rajawali Grafindo Persada, Jakarta

Almatsier.S, 2002, Prinsip Dasar Ilmu Gizi, PT Gramedia Pustaka Utama, Jakarta

...........2006, Penuntun Diet Edisi Baru, PT Gramedia Pustaka Utama, Jakarta

Bustan,M.N, 2000, Epidemiologi Penyakit Tidak Menular, Rineka Cipta, Jakarta

Candra, 2010, Tanaman Alami Penurun Trigliserida dan Kolestrol,Di akses dari: http//gaya-hidupsehat.Blokspot.com/2010/Tanaman-alamipenurun-trigliserida dan kolestrol, 09 November 2010. frekuensi konsumsi protein hewani sering, sebagian $(50.4 \%)$ responden menghidangkan jenis hidangan yang tercermin dalam susunan hidangan dengan katagori baik (gizi seimbang) sebesar $50,4 \%$ dan sebagian kecil $3,3 \%$ responden memiliki konsumsi serat yang baik sesuai dengan angka kecukupan serat untuk orang dewasa. Pada penelitian ini ada hubungan antara pola konsumsi berdasarkan susunan hidangan dengan kadar trigliserida penderita penyakit jantung serta terdapat hubungan antara asupan karbohidrat sederhana dengan kadar trigliserida penderita penyakit jantung.

Berdasarkan hasil penelitian yang telah disimpulkan diatas, peneliti menyarankan kepada pihak RSUD Dr. M.Yunus Bengkulu sebagai berikut: hendaknya lebih meningkatkan pelayanan kesehatan, hendaknya melakukan penyuluhan dan konsultasi gizi mengenai pentingnya makanan berserat dan membatasi konsumsi makanan sumber ka-rbohidrat sederhana, sedangkan kepada Pasien Penyakit Jantung sebaiknya tetap menjaga pola konsumsi dengan lebih memperhatikan sumber makanan dan frekuensi makan, mengkonsumsi serat lebih banyak (sesuai dengan anjuran yaitu $\geq 25$ gr/hari) terutama serat larut air seperti sayur-sayuran dan buah-buahan. Dan membatasi konsumsi makanan sumber karbohidrat sederhana.

Ferry dkk; 2003, Jurnal Konsumsi Karbohidrat dan Lemak dan Hubungannya dengan Daya Tahan Jantung Paru atlet sepak Bola PS Semen Padang Divisi Utama PSSI Liga Bank Mandiri IX Tahun 2003, Jurnal Klinik Gizi Indonesia

Hamid. H, 2009, Diet Terapi Pada Penyakit Jantung, Email: Zaifibio.Wordpress.com, http ://nusa indah.tripot.com, Di akses : 30 Oktober 2011

Hartono, B, 2008, Profil Kesehatan Indonesia 2006, Departemen Kesehatan RI, Jakarta

Irianto.K, 2004, Gizi dan Pola Hidup, Yrama Widya, Bandung

Jalal. F, 2006, Hubungan Lingkar Pinggang dengan Kadar Trigliserida Darah dan Tekanan Darah, Universita Andalas, Sumatera Barat 
Joseph.G, 2002, Manfaat Serat Makanan Bagi Kesehatan Kita, http://nusa indah.tripot.com. Tanggal Akses : 6 November 2010.

Komsan.A, 2004, Pangan dan Gizi untuk Kesehatan, PT Rajagrafindo Persada, Jakarta

Linder, M.C, 1992, Biokimia Nutrisi dan Metabolisme, Universitas Indonesia, Jakarta

Maryono.D, 2008, Mencegah timbulnya Penyakit Jantung dan Stroke, di akses dari: http://kesehatan-

derator.Blokspot.com/2008/09/mencegahtimbulnya-penyakit-jantung-dan html. 15 November 2010.

Mulyati.S, dkk 2007, buku Pedoman Penulisan karya Tulis Ilmiah, Kementerian Kesehatan Republik Indonesia Poloteknik kesehatan, Bengkulu
Muray,R.K dkk, 2003, Biokimia Harper edisi 25, Buku Kedokteran EGC Jakarta

Notoatmodjo.S, 2005, Metodelogi Penelitian Kesehatan, PT Asdi Mahasatya, Jakarta

Sandjaja, 2009, Kamus Gizi pelengkap Kesehatan Keluarga, Kompas, Jakarta

Sediaoetama,A.J, 2008, Ilmu Gizi untuk Mahasiswa dan Profesi Jilid I, Dian Rakyat, Jakarta

Sendi, 2008, Tentang Trigliserida, Di akses dari: http://id.wikipedia.org/wiki/Trigliserida, 09 November 2010.

Sulistijani.A, 2005, Sehat dengan Menu Berserat, Pustaka Pembangunan Nusantara, Jakarta

Supraiasa dkk, 2002, Penilaian Status Gizi, Buku Kedokteran EGC, Jakarta

Sutanto, 2001, Analisa Data, FKUI, Jakarta 